\title{
Heme Oxygenase-1 Expression in Murine Dendritic Cell Subpopulations
}

\section{Effect on $C D 8^{+}$Dendritic Cell Differentiation in Vivo}

\author{
Dong Jun Park, ${ }^{*}$ Anupam Agarwal, ${ }^{*}$ \\ and James F. George ${ }^{\star \dagger}$ \\ From the Department of Medicine," Nephrology Research and \\ Training Center, and the Department of Surgery, ${ }^{\dagger}$ Division of \\ Cardiothoracic Surgery, University of Alabama at Birmingham, \\ Birmingham, Alabama
}

Heme oxygenase-1 (HO-1) is a microsomal enzyme with antioxidant, antiapoptotic, and immunoregulatory functions. We studied the expression of HO-1 by bone marrow-derived dendritic cells (BMDCs) and splenic DC subpopulations under quiescent conditions or following lipopolysaccharide (LPS) stimulation. The kinetics of HO-1 expression by BMDCs depended on the conditions under which they were propagated. Expression of HO-1 in mouse BMDCs in $100 \mathrm{U} / \mathrm{ml}$ GM-CSF peaked at 16 hours after LPS treatment and maintained expression for at least 48 hours. But cultures in $800 \mathrm{U} / \mathrm{ml}$ granulocyte-macrophage colony-stimulating factor (GM-CSF) showed peak expression by 16 hours that disappeared by 48 hours after LPS stimulation, similar to BMDCs cultured in both $100 \mathrm{U} / \mathrm{ml} \mathrm{GM}-\mathrm{CSF}$ and IL-4 (10 ng/ml). By flow cytometry, a large proportion of $\mathrm{CD8}^{+}$splenic DCs strongly expressed HO-1, and this population significantly increased following LPS administration in vivo. In $\mathrm{HO}$ $1^{-/-}$mice, the proportion of splenic $\mathrm{CD8}^{+}$DCs was significantly decreased in comparison with $\mathrm{HO}-1^{+/+}$ mice. In addition, a unique subpopulation of MHC $\mathrm{II}^{-} \mathrm{CD11b}^{+} \mathrm{CD}_{11 c^{+}}$cells was prominent in $\mathrm{HO}-\mathrm{I}^{-/-}$ spleens. Injection of GFP-labeled $\mathrm{HO}-1^{+/+}$splenic DC precursors into $\mathrm{HO}-1^{+/+}$mice resulted in the generation of $\mathrm{GFP}^{+} \mathrm{CD8}^{+} \mathrm{DCs}$ in the spleen after 5 days, but $\mathrm{GFP}^{+} \mathrm{CD8}^{+}$DCs failed to appear in $\mathrm{HO}-1^{-/-}$spleens. Conversely, $\mathrm{GFP}^{+} \mathrm{HO}-1^{-/-}$splenic cells also generated $\mathrm{GFP}^{+} \mathrm{CD8}^{+} \mathrm{DCs}$ in $\mathrm{HO}-1^{+/+}$mice. These results show that HO-1 is involved in splenic DC differentiation, and/or the homing of $\mathrm{CD8}^{+}$splenic DC precursors appears to be dependent on HO-1 expression by the host. (Am J Pathol 2010, 176:2831-2839; DOI: 10.2353/ajpath.2010.090845)

Heme oxygenase $(\mathrm{HO})$ is an enzyme that catalyzes the rate-limiting step in the degradation of heme to biliverdin, carbon monoxide, and iron. ${ }^{1-3}$ Recently, we and others $^{4-11}$ have shown that, in addition to its well-known cytoprotective effects, $\mathrm{HO}-1$ (inducible isoform) is also involved in immune regulation. Analyses of $\mathrm{HO}-1$-deficient mice and a single reported clinical case of $\mathrm{HO}-1$ deficiency show that a systemic lack of $\mathrm{HO}-1$ results in profound immune dysregulation, characterized by a number of autoimmune lesions, as well as age-related overgrowth of $\mathrm{CD}^{+}{ }^{+} \mathrm{T}$ cells and premature death. ${ }^{12,13}$ Stimulation of $\mathrm{HO}_{-1}^{-1-}$ splenocytes with anti-CD3 and anti-CD28 results in secretion of a preponderance of Th1-type cytokines in comparison with splenocytes from normal wild-type littermates, ${ }^{12}$ and the function of regulatory $\mathrm{T}$ cells is dependent on expression of $\mathrm{HO}-1$ by the antigen-presenting cells (APCs), especially dendritic cells (DCs), ${ }^{14}$ suggesting that APCs in general, and DCs in particular, could be a key component of the immunoregulatory effects of $\mathrm{HO}-1$. If true, this hypothesis would predict that perturbation of $\mathrm{HO}-1$ expression will affect DC function. Conversely, it is also possible that DCs in

Supported by National Institutes of Health grants DK75332 and DK59600 (to A.A.), American Heart Association grant $0655318 B$ (to J.F.G.), and the core resource of the National Institutes of Health P30 O'Brien Center (DK 079337)

\section{Accepted for publication February 18, 2010.}

D.J.P. is a visiting scholar from Gyeongsang National University School of Medicine from South Korea.

Supplemental material for this article can be found on http://ajp. amjpathol.org.

Address reprint requests to James F. George, Ph.D., Department of Surgery, Division of Cardiothoracic Surgery, Room 790 LHRB; or Anupam Agarwal, M.D., Department of Medicine, Nephrology Research and Training Center, Room 647 THT, 1530 3rd Ave South, University of Alabama at Birmingham, Birmingham, AL 35294. E-mail: jgeorge@uab.edu or agarwal@uab.edu. 
different functional states or DC subpopulations associated with immune responses would exhibit differential regulation of $\mathrm{HO}-1$ expression in both the quiescent, immature state and the activated mature state. This is an important question, because DCs are not a monolithic cell lineage but are composed of a heterogeneous array of subsets that arise from a variety of precursors (for review, see Ref. 15) and are associated with diverse immune functions including $T$ cell activation, tolerance induction and maintenance, as well as integration of signals arising from innate immune responses.

A series of elegant studies has shown coupling between expression of $\mathrm{HO}-1$ and $\mathrm{DC}$ maturation, suggesting that $\mathrm{HO}-1$ can directly regulate DC maturation. ${ }^{10,16-18}$ Although specific details of this finding remain controversial, a question that remains unanswered is how HO-1 expression is regulated with respect to DC subpopulations in vivo and in vitro. The purpose of these studies was to analyze the expression of HO-1 within splenic resident DCs in the mouse because, relative to other experimental systems, murine splenic DC subpopulations are relatively well characterized, therefore allowing us to glean more specific information regarding how HO-1 affects DC differentiation in the context of physiological immune responses.

In this study, we found that expression of $\mathrm{HO}-1$ by DCs in vivo is differentially regulated among DC subpopulations in mice. We showed that $\mathrm{CD} 8^{+}$splenic DCs express high levels of $\mathrm{HO}-1$ and that differentiation or homing of $\mathrm{CD}^{+}$DCs in the murine spleen is dependent on $\mathrm{HO}-1$ expression of the host.

\section{Materials and Methods}

\section{Animals}

Male and female $\mathrm{HO}_{-1} 1^{-/}$mice (8 to 12 weeks of age) carrying a targeted deletion of a large portion of the $\mathrm{HO}-1$ gene were selected by genotyping using tail DNA as previously described from offspring of heterozygous/homozygous matings. ${ }^{19}$ Sex- and age-matched wild-type $\left(\mathrm{HO}^{-1^{+/+}}\right)$littermates were used as controls. GFP ${ }^{+}$ C57BL/6 mice expressing a transgene coding for green fluorescent protein (GFP) under control of the human ubiquitin $\mathrm{C}$ promoter have been described previously. ${ }^{20}$ We purchased these mice from The Jackson Laboratory (Bar Harbor, ME; strain: C57BL/6-Tg(UBC-GFP)30Scha/ J). $\mathrm{GFP}^{+}$mice were bred with $\mathrm{HO}-1^{+/-}$mice to generate $\mathrm{GFP}^{+} \mathrm{HO}-1^{+/+}$and $\mathrm{GFP}^{+} \mathrm{HO}-1^{-1-}$ mice. The study protocol was approved by the Institutional Animal Care and Use Committee at the University of Alabama at Birmingham (Birmingham, AL).

\section{In Vivo and in Vitro Study Design}

For the analysis of HO-1 expression of splenic DCs in vivo, we divided $\mathrm{HO}-1^{+/+}$mice into LPS treated (L2654, 2 $\mathrm{mg} / \mathrm{kg}$, i.p.; Sigma-Aldrich, St. Louis, MO) and untreated groups ( $n=3$ /group). HO-1 knockout mice were used as negative controls for flow cytometric measurements of $\mathrm{HO}-1$ expression in splenic cells or in splenic DC sub- populations. For the adoptive transfer of splenocytes from $\mathrm{GFP}^{+}$mice, we injected $10^{7} \mathrm{GFP}^{+}$splenocytes into the tail vein of $\mathrm{HO}_{-1} 1^{+/+}$mice or $\mathrm{HO}_{-1}^{-1-}$ mice $(n=$ 3/group). After 5 days, the spleen was removed and prepared for flow cytometry. Carbon monoxide-releasing molecule CORM-2 (10 mg/kg; Sigma-Aldrich, St. Louis, $\mathrm{MO}$ ) was i.v. injected into the tail vein of $\mathrm{HO}^{-1^{-1}}$ mice 2 hours before and 1,2 , and 4 days after injection of GFP ${ }^{+}$ splenocytes. Biliverdin (30 mg/kg; Aldrich Chemical, Milwaukee, WI) was i.p. injected into $\mathrm{HO}-1^{-/-}$mice 2 hours before and daily for 4 consecutive days after injection of $\mathrm{GFP}^{+}$splenocytes. Zinc protoporphyrin $(25 \mathrm{mg} / \mathrm{kg}$; Frontier Scientific, Logan, UT) was injected i.p. into $\mathrm{HO}-1^{+/+}$ mice 2 hours before and daily for 4 consecutive days. Cultured bone marrow-derived DCs (BMDCs), prepared as described below, were harvested at $0,4,8,16,24$, and 48 hours after LPS treatment (final concentration, 500 $\mathrm{ng} / \mathrm{ml})$.

\section{Splenic DC Preparation}

Spleens were harvested, cut into small fragments, minced, and digested with $100 \mathrm{U} / \mathrm{ml}$ collagenase $\mathrm{D}$ (Roche Diagnostics, Indianapolis, IN)-containing Dulbecco's PBS (Invitrogen, Grand Island, NY) solution and incubated for 20 minutes at room temperature. EDTA was added (final concentration, $0.1 \mathrm{M}$ ) to disrupt DC-T cell complexes and incubated for 5 minutes. Cells were filtered through a 70- $\mu \mathrm{m}$ stainless steel sieve (BD Falcon; $\mathrm{BD}$ Biosciences, Bedford, MA) for removing undigested fibrogenous materials and centrifuged at $300 \times g$ for 10 minutes. Supernatants were removed, and red blood cells were lysed using buffered ammonium chloride lysis solution. After cells were washed in PBS, they were used for experiments.

\section{BMDC Preparation and Culture}

Murine BMDCs were generated as previously described ${ }^{21}$ with some modifications. In brief, BM was collected from tibias and femurs of mice and flushed into plates with a syringe. Ammonium chloride lysis solution was used to lyse red blood cells for 5 minutes. At day 0 , $2 \times 10^{6} \mathrm{BM}$ cells were seeded into 6-well plates. Dulbecco's modified Eagle's medium/F-12 (Thermo Scientific, Logan, UT) supplemented with 10\% heat-inactivated fetal calf serum, L-glutamine ( $2 \mathrm{mmol} / \mathrm{L}$, Sigma-Aldrich), penicillin-streptomycin $(100 \mathrm{U} / \mathrm{ml}$ and $100 \mu \mathrm{g} / \mathrm{ml}$, respectively; Sigma-Aldrich), and 2-mercaptoethanol (50 $\mu \mathrm{mol} / \mathrm{L}$; Chemicon International, Temecula, CA) was used as culture medium. Cultures were divided into three groups: i) low-dose granulocyte-macrophage colony-stimulating factor (GM-CSF; PeproTech, Rocky Hill, NJ) (100 U/ml), ii) high-dose GM-CSF (800 U/ml), and iii) low-dose GMCSF plus IL-4 (PeproTech) $(10 \mathrm{ng} / \mathrm{ml})$. At day $3,5 \mathrm{ml}$ of medium was added to the plates without removing any medium. On day 6, nonadherent cells were harvested with gentle pipetting, and 1.5 million cells were redistributed into new 6-well plates with fresh cytokine-free me- 
dium and cultured for 24 hours. At day 7 , these cells were used for in vitro experiments.

\section{Quantitative RT-PCR}

Total RNA was isolated using TRIzol reagent (Invitrogen, Carlsbad, CA). Two micrograms of total RNA was used for synthesis of cDNA using the SuperScript III first-strand synthesis system (Invitrogen), according to the manufacturer's instructions. In brief, the first-strand cDNA synthesis reaction was primed using random hexamers (50 $\mathrm{ng} / \mu \mathrm{l}$ ) and 2'-deoxynucleoside $5^{\prime}$-triphosphates (10 $\mathrm{mmol} / \mathrm{L})$. The reaction was incubated at $65^{\circ} \mathrm{C}$ for $5 \mathrm{~min}$ utes and placed on ice for 1 minute. A cDNA synthesis mix containing $2 \mu$ l of $10 \times$ reverse transcriptase buffer, 4 $\mu \mathrm{l}$ of $25 \mathrm{mmol} / \mathrm{L} \mathrm{MgCl}_{2}, 2 \mu \mathrm{l}$ of $0.1 \mathrm{M} \mathrm{DTT}, 1 \mu \mathrm{l}$ of RNaSeOUT $(40 \mathrm{U} / \mu \mathrm{l})$, and $1 \mu \mathrm{l}$ of SuperScript III reverse transcriptase $(200 \mathrm{U} / \mu \mathrm{l})$ was added to the tube containing RNA. Reverse transcription quantitative PCRs were performed using a 7300 Real-Time PCR System (Applied Biosystems, Foster City, CA). PCR was performed in a final volume of $20 \mu \mathrm{l}$ containing $3 \mu \mathrm{l}$ of CDNA, $10 \mu \mathrm{l}$ of Brilliant SYBR Green ER (Invitrogen), $3 \mu \mathrm{l}$ of primer (10 pM), and $4 \mu$ l of distilled water. The PCR protocol was as follows: i) uracil- $N$-glycosylase step $\left(50^{\circ} \mathrm{C}\right.$ for 2 minutes); ii) initial activation step $\left(95^{\circ} \mathrm{C}\right.$ for 10 minutes); and iii) two-step cycling including denaturation $\left(95^{\circ} \mathrm{C}\right.$ for 15 seconds), and annealing/detection $\left(60^{\circ} \mathrm{C}\right.$ for 1 minute), for 40 cycles. HO-1 gene expression was normalized to the housekeeping gene glyceraldehyde-3-phosphate dehydrogenase by using the formula $2^{-\Delta \mathrm{Ct}}$ (where $\mathrm{Ct}$ is threshold cycle). The average $\mathrm{Ct}$ values for the $\mathrm{HO}-1$ and the housekeeping gene were calculated from triplicate samples. Fold expression of HO-1 mRNA is defined as the fold change in mRNA levels at each time relative to levels at an initial " 0 " time. The primers used for HO-1 were 5'-AGGTACACATCCAAGCCGAGAA-3' and 5'-CTCTGGACACTGACCCTTCTG-3' and for glyceraldehyde-3-phosphate dehydrogenase were 5'-TCCCACTCTTCCACCTTCGA-3' and 5'-AGTTGGGATAGGGCCTCTCTTG-3'.

\section{Western Blot Analysis}

BMDCs were prepared for Western blot analysis as follows: 1.5 million cells were harvested and lysed in radioimmunoprecipitation assay solution $(50 \mathrm{mM}$ Tris- $\mathrm{HCl}, 1 \%$ Nonidet P-40, 0.25\% deoxycholic acid, $150 \mathrm{mmol} / \mathrm{L} \mathrm{NaCl}$, $1 \mathrm{mmol} / \mathrm{L}$ EGTA, $1 \mathrm{mmol} / \mathrm{L}$ sodium orthovanadate, and 1 $\mathrm{mmol} / \mathrm{L}$ sodium fluoride) with protease inhibitors (Roche Applied Science, Indianapolis, IN). The lysates were sonicated several times for 1 minute and centrifuged at $300 \times g$ for 10 minutes at $4^{\circ} \mathrm{C}$. The protein concentration of each lysate was determined by using the BCA assay (Thermo Scientific, Rockford, IL). Equal amounts of protein $(10 \mu \mathrm{g})$ were loaded onto a $12 \%$ SDS-polyacrylamide gel. After electrophoresis, proteins in the gel were transferred to a nitrocellulose membrane (Hybond C-Extra; Amersham Biosciences, Piscataway, NJ). Membranes were blocked with 5\% nonfat dried milk in PBS containing
0.1\% Tween-20 and probed with anti-HO-1 antibodies (Abs) (SPA 896, 1/5000; StressGen Biotechnologies, Victoria, British Columbia, Canada). Membranes were stripped and reprobed with actin as a loading control. Immunoreactive bands were detected using horseradish peroxidase-linked $\mathrm{Ab}$ against rabbit IgG and visualized with enhanced chemiluminescence kit (Santa Cruz Biotechnology, Santa Cruz, CA), to the manufacturer's instructions.

\section{Flow Cytometry}

Cells were washed once with cold PBS and were incubated for 10 minutes at room temperature with antimouse CD16/32 (eBioscience, San Diego, CA) to block nonspecific binding to $\mathrm{FC} \gamma 3$ receptors. Cells were initially stained with fluorescein isothiocyanate-conjugated (FITC) anti-mouse CD86 (clone GL-1), phycoerythrin (PE)-conjugated anti-mouse CD19 (clone 1D3), antimouse CD11c biotin (clone HL3), and APC-conjugated anti-mouse major histocompatibility complex class II (MHC II) (clone M5/114.15.2) for 30 minutes on ice. Cells were washed and stained with (PerCP)-conjugated antimouse streptavidin for additional 30 minutes on ice. PE-, FITC-, and APC-conjugated isotype matched Abs of irrelevant specificity were used as controls. All Abs were purchased from BD Pharmingen (San Diego, CA) or eBioscience. For intracellular HO-1 staining in splenic DCs, cells were fixed using 2\% formaldehyde (Polysciences, Warrington, PA) for 10 minutes at room temperature and centrifuged for 10 minutes at $300 \times \mathrm{g}$. Ice-cold methanol was added to the cells and incubated on ice for an additional 10 minutes. Cells were washed twice with cold staining solution (PBS, $0.02 \%$ sodium azide, and $5 \%$ bovine serum albumin) and stained with unconjugated rabbit anti-mouse HO-1 Ab (SPA 895; StressGen Biotechnologies), PerCP-conjugated anti-mouse CD4 (clone L3T4) or CD8 Ab (clone 53-6.7), PE-conjugated antimouse $\mathrm{CD} 11 \mathrm{C} \mathrm{Ab}$ (clone HL3), and Alexa 647-conjugated CD8 Ab (clone 53-6.7) or APC-conjugated antimouse CD11b Ab (clone M1/70) for 30 minutes on ice. After washing, cells were stained with FITC-conjugated goat anti-rabbit lgG secondary $\mathrm{Ab}$ for 30 minutes on ice. PE-, PerCP-, and APC-conjugated Abs and rabbit Abs of irrelevant specificity were used as isotype controls. DC subsets in $\mathrm{HO}-1^{+/+}$mice and $\mathrm{HO}-1^{-/-}$mice were identified by incubation with FITC-conjugated, PE-conjugated, PerCP-conjugated and APC-conjugated mAb specific for CD11c, CD4, CD8, and MHC II, respectively. Data acquisition was performed on a FACSCalibur flow cytometer (BD Biosciences), and results were analyzed using Winlist software (Verity Software House, Topsham, MA).

\section{Statistical Analysis}

Values are expressed as mean \pm SE. Analyses were performed using analysis of variance and the StudentNewman-Keuls test. Differences were considered statistically significant when the $P$ value was $<0.05$. 
A
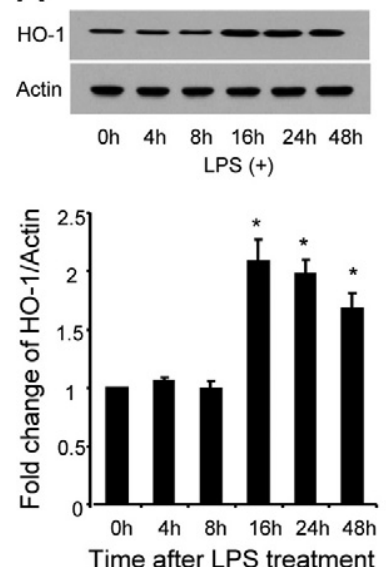

Time after LPS treatment
B
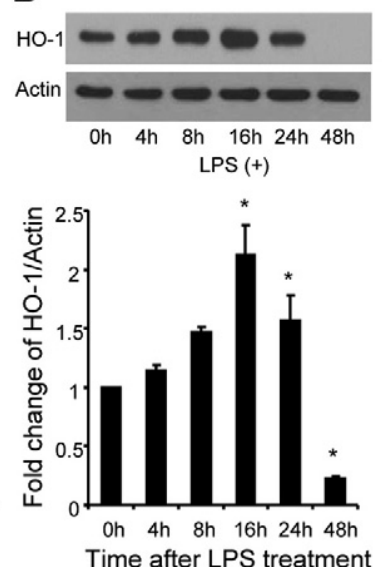

Time after LPS treatment
C
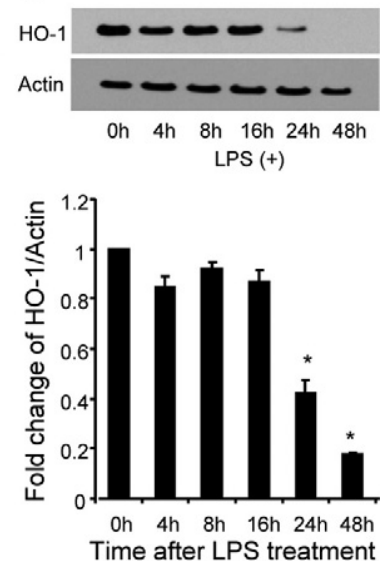

Figure 1. Kinetic analyses of HO-1 protein expression in BMDCs with respect to culture conditions after LPS-induced maturation. BMDCs were cultured in GM-CSF at $100 \mathrm{U} / \mathrm{ml}(\mathbf{A}), \mathrm{GM}-$ $\mathrm{CSF}$ at $800 \mathrm{U} / \mathrm{ml}(\mathbf{B})$, and GM-CSF $(100 \mathrm{U} / \mathrm{ml})$ plus IL-4 (10 ng/ml) (C) for the indicated times. The blots shown in this figure are representative of three separate experiments with similar results. Actin was used as a loading control. The histograms represent densitometry analysis of HO-1 bands normalized to actin and are expressed as the fold change relative to time 0 ( ${ }^{*} P<0.05$ versus " 0 " time value)

\section{Results}

\section{HO-1 Expression by BMDCs in Vitro}

Figure 1A shows expression of $\mathrm{HO}-1$ as measured by Western blot analysis in BMDC cultures propagated for 6 days in $100 \mathrm{U} / \mathrm{ml} \mathrm{GM-CSF}$. Under these conditions, HO-1 expression was readily detectable for at least 48 hours following stimulation by LPS. In contrast to previous reports, ${ }^{17}$ we did not observe a diminution of $\mathrm{HO}-1$ expression with respect to maturation, as determined by expression of increased levels of the costimulatory molecule, CD86, and surface MHC II molecules (Figure 2A). However, increasing the concentration of GM-CSF used to propagate the BMDCs from 100 to $800 \mathrm{U} / \mathrm{ml}$ resulted in a change in this behavior, as shown in Figure 1B. $\mathrm{HO}-1$ expression peaked by 16 hours poststimulation and was nearly absent by 48 hours poststimulation. Again, we observed a concomitant increase in the expression of both CD86 and MHC II, indicating that the LPS treatment promoted DCs to maturation (Figure 2A). The inclusion of IL-4 with the GM-CSF resulted in lower levels of $\mathrm{HO}-1$ in comparison with the other two conditions, but by 24 hours, the levels of $\mathrm{HO}-1$ also began to drop and were nearly undetectable by 48 hours (Figure 1C). The proportion of $\mathrm{CD}_{11 \mathrm{C}^{+}}$cells was similar in low GM-CSF and high
GM-CSF culture conditions, whereas the addition of IL-4 increased this proportion (Supplemental Figure 1, see http://ajp.amjpathol.org). The highest proportion of mature BMDCs, as determined by increased expression of CD86 and $\mathrm{MHC} \mathrm{II}$, also occurred in these cultures. It is interesting to note that the most rapid and complete transition to $\mathrm{CD} 86^{\text {hi }} / \mathrm{MHC}$ II $^{\text {hi }}$ phenotype was achieved in the cultures propagated in low-dose GM-CSF and IL-4 (Figure 2A). HO-1 mRNA levels measured by real-time PCR (Figure $2 \mathrm{~B}$ ) appeared to reflect the trends observed using western blots. Cultures containing $100 \mathrm{U} / \mathrm{ml}$ GM-CSF expressed the highest levels of HO-1 mRNA, achieving peak expression by 16 hours after stimulation with LPS (12-fold versus time $0 ; P<0.05$ ). $\mathrm{HO}-1$ expression was not detectable in BM cells immediately following isolation in the presence or absence of GM-CSF alone or GM-CSF plus IL-4 for 16 hours (data not shown), suggesting that in the progenitor state these growth factors do not induce $\mathrm{HO}-1$.

\section{HO-1 Expression in Splenic DCs in the Steady-State in Vivo Following LPS Administration}

Steady-state murine $\mathrm{CD} 11 \mathrm{C}^{+} / \mathrm{MHC} \mathrm{I}^{+}$resident splenic DCs can be subdivided into three subpopulations based
A

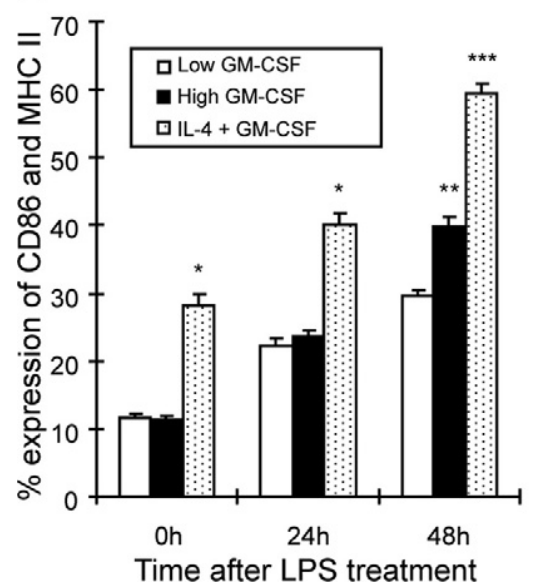

Time after LPS treatment
B

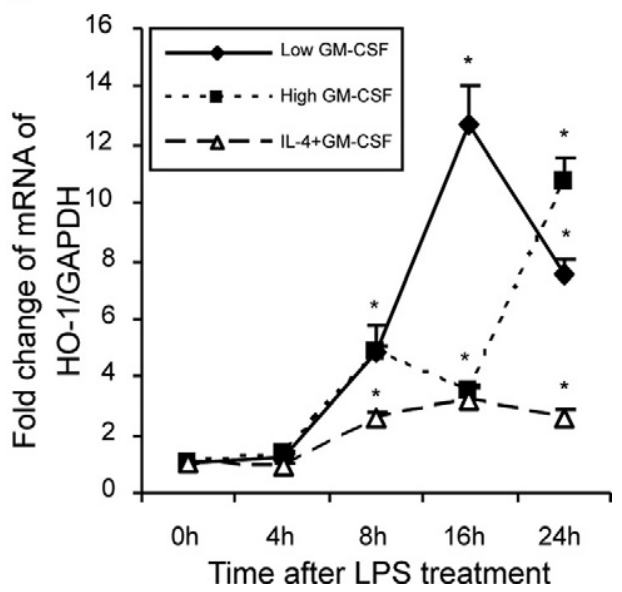

Figure 2. Expression of MHC II, CD86, and HO-1 mRNA by BMDCs propagated in different culture conditions in the presence of LPS. A: BMDCs were cultured in GM-CSF at $100 \mathrm{U} / \mathrm{ml}$ (white bar), GM-CSF at $800 \mathrm{U} / \mathrm{ml}$ (black bar), and GM-CSF $(100 \mathrm{U} / \mathrm{ml})$ plus IL-4 $(10 \mathrm{ng} / \mathrm{ml})$ (gray bar). The histogram depicts the mean proportion of cells positive for both CD86 and MHC II in each culture condition $(n=5) .{ }^{*} P<0.05$ : low or high GM-CSF versus IL-4 plus GM-CSF at 0 and 24 hours. ${ }^{* *} P<0.05$ : low GM versus high GM-CSF at 48 hours. ${ }^{* * *} P<0.05$ : low GM-CSF versus IL-4 plus GM-CSF at 48 hours. B: BMDCs were cultured in GM-CSF at $100 \mathrm{U} / \mathrm{ml}$ (closed diamond), GM-CSF at $800 \mathrm{U} / \mathrm{ml}$ (closed box), and GM-CSF $(100 \mathrm{U} / \mathrm{ml})$ plus IL-4 $(10 \mathrm{ng} / \mathrm{ml})$ (open triangle) for the indicated time. Data shown represent the mean expression relative to time $0 \pm$ SEM for three independent experiments. " $P<0.05$ versus "0" time value. 
A

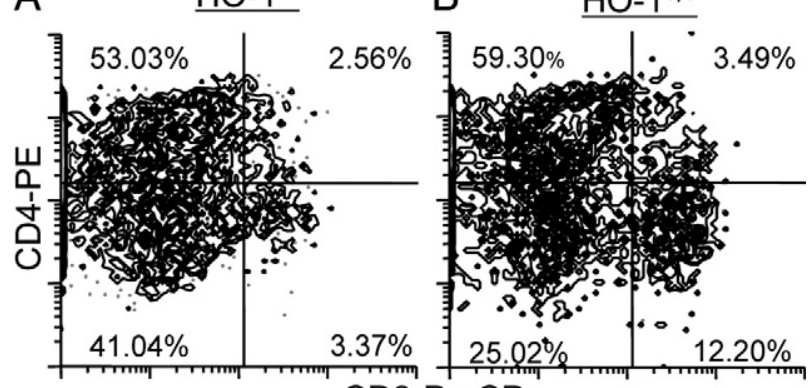

CD8-PerCP

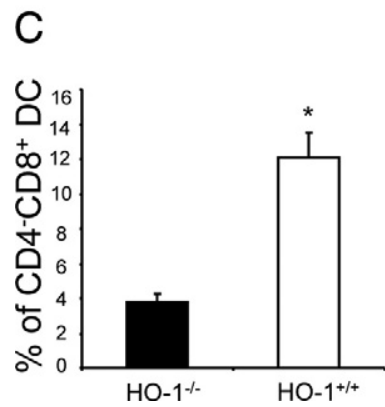

$\mathrm{D}$

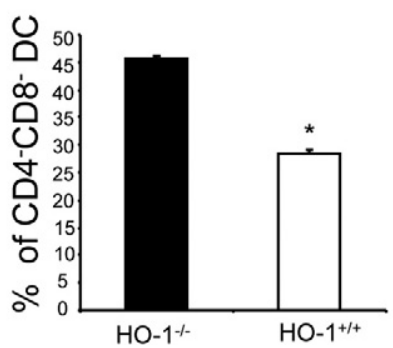

Figure 3. DCs from $\mathrm{HO}-1$ knockout mice are deficient in the $\mathrm{CD} 8^{+} \mathrm{DC}$ subset. Splenic cells from both wild-type mice and HO-1 knockout mice were harvested as described in Materials and Methods. CD8 and CD4 expression is shown on CD11c and MHC II-gated cells from knockout mice (A) and wild-type mice (B). Figures are representative of three separate experiments. Numbers within graph quadrants depict the percentage of $\mathrm{CD} 11 \mathrm{c}^{+} \mathrm{MHC} \mathrm{II}^{+}$ positive cells. The histograms shown depict the average from three animals in the percentage of $\mathrm{CD}^{-} \mathrm{CD}^{+} \mathrm{DC}(\mathbf{C})$ and $\mathrm{CD} 4^{-} \mathrm{CD} 8^{-}$cells $(\mathbf{D})$ in wildtype mice and knockout mice $\left(n=3 ;{ }^{*} P<0.05\right)$.

on their expression of $\mathrm{CD} 4$ and $\mathrm{CD} 8$ : $\mathrm{CD}^{-}{ }^{-} \mathrm{CD} 8^{-}$, $\mathrm{CD} 4^{+} \mathrm{CD} 8^{-}$, and $\mathrm{CD} 4^{-} \mathrm{CD} 8^{+} .{ }^{15,22}$ Figure $3 \mathrm{~A}-\mathrm{D}$ represents the distribution of CD4 and CD8 staining on splenic $\mathrm{DCs}$, defined as $\mathrm{CD} 11 \mathrm{c}^{+} / \mathrm{MHC} \mathrm{II}^{+}$cells isolated after collagenase digestion of spleens to release $\mathrm{CD}^{+} \mathrm{DCs}$ from the periarteriolar sheaths. As previously reported, ${ }^{15,22,23}$ the majority of cells was $\mathrm{CD} 4^{+}$, with significant $\mathrm{CD} 4^{-} \mathrm{CD}^{+}$and $\mathrm{CD} 4^{-} \mathrm{CD} 8^{-}$subpopulations. Typically, these subpopulations are enumerated after $\mathrm{Ab}$ and complement or immunomagnetic bead depletion. ${ }^{22,23}$ However, these procedures were avoided because in vitro manipulations activate the $\mathrm{HO}-1$ gene and also drive DCs to mature. ${ }^{24,25}$ To reduce contamination of the signal by intact, viable, autofluorescent cells that appear to be monocytes/macrophages, selective gating of DCs on the basis of CD11C and MHC II expression was done. We first determined the distribution of DC subpopulations in the spleens of HO-1-deficient mice in comparison with wild-type littermates and then determined whether there were differences in the expression of $\mathrm{HO}-1$ in these cells. As negative controls, we used cells from $\mathrm{HO}$-1-deficient animals to determine background staining. The distribution of these subpopulations is significantly changed in mice lacking HO-1 (Figure 3). Most notably, the proportion of $\mathrm{CD}^{+} \mathrm{DCs}$ is greatly reduced in $\mathrm{HO}-1$-deficient mice $\left(H O-1^{+/+}=12.05 \pm 1.42\right.$ versus $H O-1^{-/-}=3.79 \pm$ $0.46 ; n=3 ; P=0.016)$, and the proportion of $\mathrm{CD}^{-}{ }^{-} \mathrm{CD} 8^{-}$ $\mathrm{DC}$ is significantly increased $\left(\mathrm{HO}-1^{+/+}=28.32 \pm 0.81\right.$ versus $\left.\mathrm{HO}-1^{-1-}=45.68 \pm 0.55 ; n=3 ; P=0.003\right)$ relative to the wild-type littermates. When these same

A

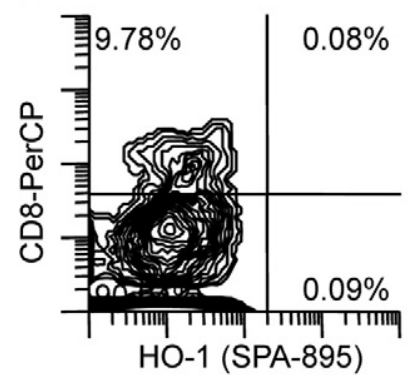

B

C

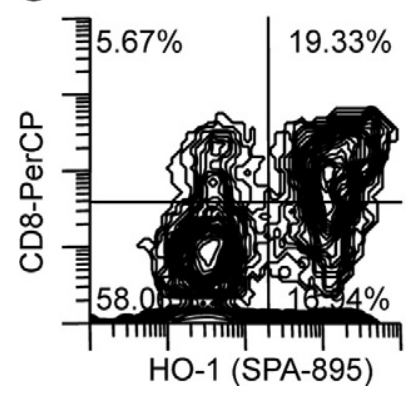

D
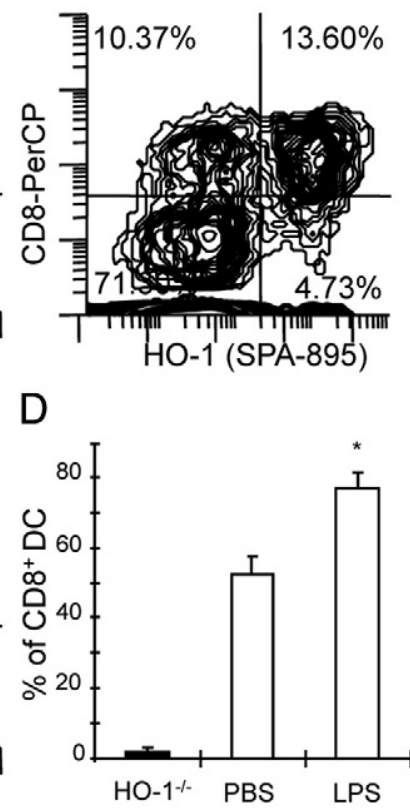

Figure 4. $\mathrm{CD}^{+}$splenic DCs express $\mathrm{HO}-1$ protein in vivo. Coexpression of CD8 and HO- 1 in splenic DCs from $\mathrm{HO}_{-1}^{-/-}(\mathbf{A})$, PBS-injected wild-type mice $(\mathbf{B})$, and LPS-treated wild-type mice $(\mathbf{C})$. Figures are representative of three separate experiments. Numbers within graph quadrants are the percentage of $\mathrm{CD}_{11 \mathrm{C}^{+} \mathrm{MHC} \mathrm{II}}{ }^{+}$positive cells. The histogram (D) shows the average of three experiments expressed as the proportion of $\mathrm{CD}^{+}$cells expressing HO-1 divided by total $\mathrm{CD}^{+}$cells in HO-1 wild-type mice 24 hours after PBS and LPS administration ( $n=3$ in each group; ${ }^{*} P<0.05$ ).

subpopulations were evaluated for expression of $\mathrm{HO}-1$ by flow cytometry, we found that most DCs stain weakly or are negative for expression of $\mathrm{HO}-1$ in vivo, with the exception of the $\mathrm{CD} 8^{+}$subpopulation, among which the majority exhibited strong expression of $\mathrm{HO}-1$ (Figure 4, A and $\mathrm{B}$ ).

To determine whether the expression of $\mathrm{HO}-1$ changed among these subpopulations in vivo relative to LPS-induced maturation, the expression of $\mathrm{HO}-1$ in $\mathrm{DC}$ subpopulations was determined after LPS administration in vivo. Wild-type mice were injected with LPS, and the splenocytes were then analyzed for $\mathrm{HO}-1$ expression at 24 hours. As in the steady-state animals, $\mathrm{CD} 8^{+} \mathrm{DCs}$ remained the predominant $\mathrm{HO}-1$-expressing subpopulation. The proportion of $\mathrm{CD}^{+} \mathrm{DCs}$ expressing $\mathrm{HO}-1$ increased from $52.53 \pm 4.67$ to $76.59 \pm 4.76$ (Figure 4 , C and D). Further examination of $\mathrm{CD} 11 \mathrm{c}^{+}$subpopulations revealed the existence of apparently unique $\mathrm{CD}_{11 \mathrm{~b}}{ }^{+} /$ $\mathrm{CD}_{11 \mathrm{C}^{+}}$cells in $\mathrm{HO}-1$-deficient mice $(7.70 \pm 1.74$ versus $1.25 \pm 0.41$ in wild-type; $P=0.0002$ ) (Figure $5, A-C$ ). Phenotypic analysis showed that the majority of these cells is CD11b+ $\mathrm{b}^{+}, \mathrm{MC} \|^{\mathrm{lo}}, \mathrm{CD}^{+} 4^{+}, \mathrm{CD} 45 \mathrm{RA} \mathrm{A}^{\mathrm{int}}$, and Ly6c $^{+}$(Figure 5, D-F).

\section{Differentiation of $C D 8^{+}$Splenic DCs from Late Precursors in HO-1-Deficient Mice}

$\mathrm{CD}^{+}$DCs are short-lived with a life span of $<3$ days, and they arise from intrasplenic $\mathrm{CD} 8^{-}$precursors. ${ }^{15,23,26}$ To determine whether the development of $\mathrm{CD}^{+} \mathrm{DCs}$ or 

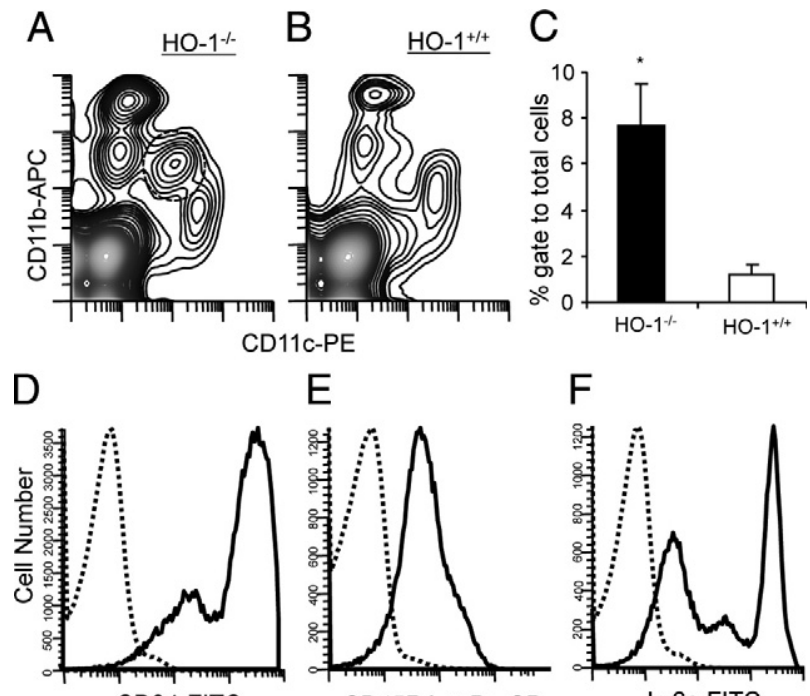

CD24-FITC
$\mathrm{F}$

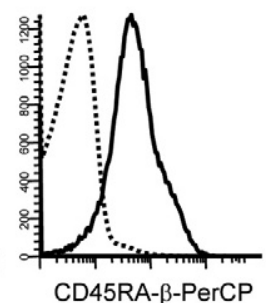

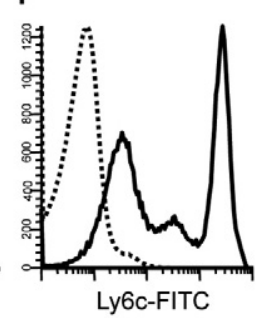

Figure 5. A unique splenic DC subpopulation in HO-1 knockout mice. Splenic cells from both HO-1 knockout mice (A) and wild-type mice (B) were gated on MHC II and plotted with respect to CD11c and CD11b staining. Cells gated as shown by the dotted line in $\mathbf{A}$ were analyzed for expression of CD24 (D), CD45RA (E), and Ly6c (F). Figures are representative of five separate experiments. The histogram $(\mathbf{C})$ depicts the mean percentage of total gated cells in knockout mice $\left(\mathrm{HO}-1^{-/-}\right)$and wild-type mice $\left(\mathrm{HO}-1^{+/+}\right)$, respectively $\left(n=5 ;{ }^{*} P<0.05\right)$. Dotted line: isotype control.

their precursors are dependent on $\mathrm{HO}-1$, we used a modification of a previously described ${ }^{15}$ late precursor assay to show that steady-state splenic $\mathrm{CD}^{+} \mathrm{DCs}$ arise from a nonmonocyte splenic precursor. We adoptively transferred splenocytes from GFP ${ }^{+}$transgenic mice ${ }^{20}$ to HO-1-deficient mice or their wild-type littermates. Five days later, the spleens of the recipient mice were analyzed for the presence of GFP-labeled DCs. Because $\mathrm{CD}^{+}$DCs already present in the GFP-labeled spleen cells live $<3$ days, it was presumed that $\mathrm{GFP}^{+} \mathrm{CD}^{+} \mathrm{DCs}$ observed in the recipient mouse at 5 days postinfusion arose from the transferred $\mathrm{GFP}^{+}$precursors.

Flow cytometry analysis of splenocytes from wild-type or $\mathrm{HO}-1^{-/-}$mice injected 5 days previously with GFPlabeled wild-type splenocytes showed significant differences in the distribution of GFP-labeled DC subpopulations. Figure $6 \mathrm{~B}$ shows that $\mathrm{GFP}^{+}$-labeled $\mathrm{CD} 8^{+} \mathrm{DC}$ can be found in $\mathrm{HO}_{-1} 1^{+/+}$mice injected with $\mathrm{GFP}^{+}$splenocytes. In contrast, GFP-labeled CD8 ${ }^{+}$DCs were detected with a much lower frequency in the spleens of $\mathrm{HO}_{-1} 1^{-/-}$ mice injected with cells prepared from the same GFP ${ }^{+}$ splenocyte preparations (Figure 6, A and C). To determine whether late precursors for $\mathrm{CD}^{+} \mathrm{DC}$ s were present in the spleens of $\mathrm{HO}-1^{-1-}$ mice, we performed adoptive transfer of splenocytes from $\mathrm{GFP}^{+} \mathrm{HO}_{-1} 1^{-/-}$mice into both $\mathrm{GFP}^{-} \mathrm{HO}-1^{+/+}$and $\mathrm{HO}-1^{-/-}$mice. Few GFP-labeled $\mathrm{CD}^{+} \mathrm{DCs}$ were found in $\mathrm{HO}-1^{-1-}$ mice, whereas $\mathrm{GFP}^{+}$. labeled $\mathrm{CD}^{+}$DCs were found in $\mathrm{HO}_{-1}{ }^{+/+}$mice injected with $\mathrm{GFP}^{+}$splenocytes in numbers comparable with mice injected with $\mathrm{HO}-1^{+/+}$cells (Figure 6, D-F). These results indicate that absence of GFP-labeled CD8 ${ }^{+}$DCs in $\mathrm{HO}_{-1}^{-1-}$ mice is not caused by a lack of precursor cells but may result from a failure of splenic $\mathrm{CD}^{+} \mathrm{DC}$

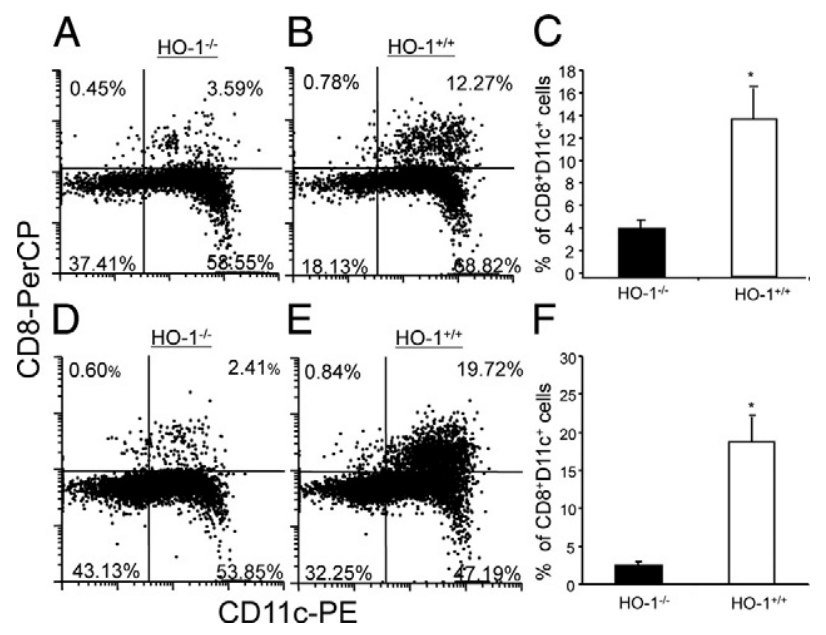

Figure 6. Development of late DC precursors into $\mathrm{CD}^{+}$DCs in $\mathrm{HO}-1-$ deficient mice. Splenocytes $\left(1 \times 10^{7}\right)$ from $\mathrm{GFP}^{+} \mathrm{B} 6$ mice and $\mathrm{GFP}^{+} \mathrm{HO}-$ $1^{-/-}$mice were i.v. injected into $\mathrm{HO}-1^{-/-}$and $\mathrm{HO}-1^{+/+}$mice. Spleens from these mice were harvested 5 days after injection, and cells were used for analysis of data. Cells shown were gated on $\mathrm{GFP}^{+}$and $\mathrm{MHC} \mathrm{II}^{+}$events. Plots show the appearance of CD11c ${ }^{+} \mathrm{CD}^{+}$DCs in the spleens of $\mathrm{HO}_{-} 1^{-/}$(A and D) and $\mathrm{HO}-\mathrm{I}^{+/+}(\mathbf{B}$ and $\mathbf{E})$ mice receiving adoptively transferred splenocytes from $\mathrm{GFP}^{+} \mathrm{B} 6(\mathbf{A}-\mathbf{C})$ and $\mathrm{GFP}^{+} \mathrm{HO}-1^{-/-}(\mathbf{D}-\mathbf{F})$ mice. Numbers within each quadrant are the percentage of gated cells. $\mathbf{C}$ and $\mathbf{F}$ show the mean and SEM of $\mathrm{CD} 11 \mathrm{c}^{+} \mathrm{CD}^{+}$splenocytes detected in recipient mice (genotype indicated on the $x$-axis) in three separate experiments ( $n=3$ /group; ${ }^{*} P<0.05$ ).

precursors to home or differentiate into $\mathrm{CD}^{+} \mathrm{DC}$ in the spleens of $\mathrm{HO}$-1-deficient mice.

To determine whether the degradation products of heme could correct the effects of $\mathrm{HO}-1$ deficiency, we treated $\mathrm{HO}-1^{-1-}$ mice with the carbon monoxide releasing molecule CORM-2 or biliverdin just before adoptive transfer of $\mathrm{GFP}^{+}$splenocytes and then daily until spleen removal. Neither CORM-2 nor biliverdin was able to restore normal numbers of $\mathrm{GFP}^{+} \mathrm{CD}^{+} \mathrm{DCs}$ in $\mathrm{HO}-1^{-1-}$. recipient mice $(2.38 \pm 0.36$ and $1.49 \pm 0.03$ in the CORM-2- and biliverdin-treated groups, respectively, versus $1.25 \pm 0.41$ in the untreated $\mathrm{HO}^{-1^{-1-}}$ group, $n=$ 3; $P=\mathrm{ns}$ ). To determine whether there was a direct relationship between $\mathrm{HO}-1$ expression and $\mathrm{DC}$ differentiation, we treated $\mathrm{HO}_{-} 1^{+/+}$mice with the $\mathrm{HO}$ inhibitor zinc protoporphyrin but found no suppression of the splenic $\mathrm{CD}^{+}$DCs in $\mathrm{HO}-1^{+/+}$mice (12.39 \pm 0.52 in zinc protoporphyrin-treated group versus $12.05 \pm 1.42$ in the control group; $n=3 ; P=n s)$. These results suggest that $\mathrm{HO}-1$ deficiency affects homing or differentiation of $\mathrm{CD}^{+}$ DCs indirectly by altering the development or seeding of cells present within the splenic microenvironment.

\section{Discussion}

The results described in this paper have generated four key findings: i) the kinetics of $\mathrm{HO}-1$ expression in BMDCs in response to LPS is dependent on the conditions under which the BMDCs are cultured; ii) as previously reported, BMDCs lose expression of $\mathrm{HO}-1$ because they are driven to maturation by LPS, ${ }^{17}$ but only under specific conditions; iii) in the spleen under quiescent conditions and in the presence of LPS, CD8 ${ }^{+}$DCs very strongly express $\mathrm{HO}-1$ relative to other subpopulations; and iv) $\mathrm{HO}-1$ may 
play a role in the differentiation of $\mathrm{CD} 8^{+} \mathrm{DCs}$ from precursors, or alternatively, may affect the homing of DC precursors. HO-1 is involved in recycling of heme components in the course of normal metabolism within the APCs but is also integral in the catabolism of hemecontaining proteins from materials acquired by phagocytosis or pinocytosis, which are major modes of acquisition of moieties ultimately presented as antigens. Therefore, $\mathrm{HO}-1$, an inducible gene product, would be expected to be relatively abundant in cells involved in antigen presentation. Previous studies have shown that $\mathrm{HO}-1$ can be readily detected in monocytes/macrophages as well as DCs. However, recent evidence has suggested that $\mathrm{HO}-1$ is involved in the differentiation, maturation, and function of DCs.

Our results provide a potential explanation for data obtained by different laboratories showing that inhibition of BMDC maturation may be $\mathrm{HO}-1$ dependent ${ }^{17}$ or independent. ${ }^{18}$ It is common to propagate BMDCs under a variety of conditions ranging from 100 to $1000 \mathrm{U} / \mathrm{ml} \mathrm{GM}$ CSF with or without IL-4. ${ }^{22,27,28}$ We found that BMDCs propagated in lower concentrations of GM-CSF (100 $\mathrm{U} / \mathrm{ml}$ ) in the absence of IL-4 did not exhibit a detectable decrease in $\mathrm{HO}-1$ expression in the presence of LPS. Higher concentrations of GM-CSF (ie, $800 \mathrm{U} / \mathrm{ml}$ ) or the use of GM-CSF and IL-4 propagated BMDCs that downregulated expression of HO-1 in response to LPS. These results illustrate the limitations of in vitro experimental systems that rely on the use of BMDC for making general conclusions regarding the role of $\mathrm{HO}-1$ in $\mathrm{DC}$ function but do not detract from the strength of studies in which $\mathrm{HO}-1$ levels or its products are manipulated in BMDCs for potential therapeutic purposes. ${ }^{16,17}$

It has been suggested that murine BMDCs are able to promote antitumor activity, ${ }^{29,} 30$ and the maturation status of BMDCs is important in the induction of antitumor immunity. ${ }^{29}$ Immature BMDCs may induce tolerance, whereas mature BMDCs are necessary for antigen processing and presentation. ${ }^{30}$ Our studies show that $\mathrm{HO}-1$ expression in response to LPS is dependent on culture conditions and that BMDCs grown in the presence of IL-4 contain a greater proportion of mature cells. Length polymorphisms in a (GT)n repeat region in the proximal HO-1 promoter can also affect levels of $\mathrm{HO}-1$ expression and modulate disease development. ${ }^{31}$ If, as suggested by the results of Chauveau et al, ${ }^{17}$ that $\mathrm{HO}-1$ can also impact DC maturation, then proper control of $\mathrm{HO}-1$ expression under specific culture conditions could result in BMDCs that more effectively induce antitumor activity. This could be of potential benefit in cancer patients where DCs are being increasingly considered as cell-based therapy.

To obtain information regarding the role of $\mathrm{HO}-1$ in $\mathrm{DCs}$ in a physiological milieu, we examined patterns of expression in resident splenic DC subpopulations and found, in agreement with previous studies in the rat, ${ }^{17}$ not all DC subpopulations express equal quantities of $\mathrm{HO}-1$ as detected by immunofluorescence. We found that only high levels of HO-1 could be reliably detected by flow cytometry using the SPA-895 polyclonal rabbit anti-HO-1 $\mathrm{Ab}$. It is notable that the splenic DC subpopulations expressing the highest levels of $\mathrm{HO}-1$ were $\mathrm{CD}^{+} \mathrm{DCs}$. This subpopulation resides within the periarteriolar sheaths and marginal zones of the spleen and is thought to participate in immunoregulatory pathways. Interestingly, $\mathrm{CD} 8^{+} \mathrm{DC}$ appear to be largely absent in $\mathrm{HO}_{-1^{-1-}}$ mice, which exhibit a variety of abnormalities, including inflammatory lesions with increasing age. This suggests that there could be a relationship between the observed abnormalities, the lack of $\mathrm{HO}-1$, and the apparent absence of $C D 8^{+}$DCs. This possibility is supported by the results of the late precursor assays in which GFP-labeled wildtype splenocytes infused into $\mathrm{HO}_{-1}^{-1-}$ mice failed to generate GFP-labeled $\mathrm{CD}^{+} \mathrm{DCs}$ in vivo in comparison with the control wild-type mice.

Several lines of evidence support the idea that $\mathrm{HO}-1$ is involved in both adaptive and innate immune responses. As noted above, $\mathrm{HO}-1^{-/-}$mice have a number of immunological abnormalities, including age-related accumulation of $\mathrm{CD} 4^{+}$cells, and significantly enhanced production of proinflammatory cytokines by their splenocytes in response to LPS, ${ }^{12}$ Up-regulation of $\mathrm{HO}-1$ can prolong allograft survival. ${ }^{32-38} \mathrm{HO}-1$-deficient mice have a reduced life span, apparently resulting from immunological dysregulation as well as other issues, including the accumulation of iron in the tissues. ${ }^{12,13}$ Similar abnormalities were reported in a case of HO-1 deficiency in a human who, in addition, had marked atherosclerosis. ${ }^{39-41}$ Given the results reported in this work as well as those discussed above, it is arguable that a significant reason for the observed immunological abnormalities is dysregulation of APC differentiation and function. In previous studies, we showed that $\mathrm{HO}-1$-deficient splenic APCs as well as $\mathrm{HO}_{-1} 1^{-1-}$ BMDCs fail to support regulatory $T$ cell-mediated suppression in vitro. ${ }^{14}$ Here we report abnormalities in the distribution of DC subpopulations in $\mathrm{HO}_{-1} 1^{-1-}$ mice, and that $\mathrm{CD} 8^{+} \mathrm{DCs}$ fail to appear in late precursor assays of $\mathrm{HO}^{-1^{-1}}$ mice in vivo, despite the fact that precursors of $\mathrm{CD}^{+} \mathrm{DCs}$ appear to be present in the spleens of $\mathrm{HO}_{-1}^{-1-}$ mice. The data are consistent with findings in which induction of $\mathrm{HO}-1$ inhibits LPS-induced DC maturation and cytokine production $^{10,17,18,42}$ as well as reducing the ability to support T cell activation by polyclonal or allogeneic stimulation. ${ }^{12,17,42}$ However, the role of $\mathrm{HO}-1$ in DC function and differentiation in vivo remains largely unexplored because the majority of data have been generated using DCs propagated from BM cells in the presence of GM-CSF with or without IL-4. Although this approach has been informative, it does not answer the question of why HO-1 deficiency results in such profound immunological abnormalities and what role $\mathrm{HO}-1$ expression in the DC lineage plays in regulation of the immune response.

The DC lineage is markedly heterogeneous, with an array of subpopulations characterized by different surface antigens, phenotypes, and tissue distributions. Conventional mouse DCs can be delineated by expression of $\mathrm{CD} 4$ and $\mathrm{CD} 8$ as $\mathrm{CD} 4^{-} \mathrm{CD} 8^{-}, \mathrm{CD} 4^{+} \mathrm{CD} 8^{-}$, and $\mathrm{CD}^{-} \mathrm{CD} 8^{+}$subsets. ${ }^{15,23,43-45}$ We found that, among DCs in the spleen, $\mathrm{CD}^{+} \mathrm{DC}$ exhibit prominent expression of HO-1. The functional significance of these high expression levels is unclear, although characterization of DC subsets in $\mathrm{HO}_{-1}^{-1-}$ mice suggests that the differen- 
tiation of $\mathrm{CD}^{+} \mathrm{DCs}$ or the homing of their precursors may be dependent on systemic expression of HO-1. In normal mice, late precursors for $\mathrm{CD} 8^{+} \mathrm{DCs}$ can be found in the spleen. Shortman and colleagues ${ }^{15,23}$ have characterized these precursors and found that they can be adoptively transferred by i.v. injection to host mice in which they give rise to splenic $\mathrm{CD} 8^{+} \mathrm{DCs}$. Using splenocytes from $\mathrm{GFP}^{+}$mice, we replicated these results in normal host mice but found that transfer of precursors into $\mathrm{HO}-1^{-1-}$ mice resulted in only very small number of $\mathrm{GFP}^{+} \mathrm{CD}^{+} \mathrm{DCs}$ in the host spleen.

The decrease in the proportion of $\mathrm{CD}^{+} \mathrm{DCs}$ in the spleens of $\mathrm{HO}_{-1} 1^{-1-}$ mice in the adoptive transfer experiments can be explained by several mechanisms. First, it is possible that $\mathrm{HO}-1$ deficiency results in a defect in a later stage of differentiation of pre-DCs into DCs in the spleen but has no effect on homing capacity. A second possibility is that $\mathrm{HO}-1$ deficiency in the recipient animal results in the death of the labeled precursors before arrival to the spleen, although a more likely scenario in the "failure to arrive" hypothesis would be sequestration of the cells in places other than the spleen-perhaps the liver, which is also one of the first places in which particulate materials tend to arrive and accumulate after intravenous injection. Our results support the idea that $\mathrm{HO}-1$ deficiency in the host plays a major role in the appearance of labeled CD8 ${ }^{+}$DCs in spleen. The appearance of normal proportions of $\mathrm{GFP}^{+} \mathrm{CD}^{+} \mathrm{DC}$ s in the spleens of $\mathrm{HO}-1^{+/+}$adoptive transfer recipients that received splenocytes from $\mathrm{GFP}^{+} \mathrm{HO}_{-1}{ }^{-1-}$ mice indicates that the precursors to $\mathrm{CD}^{+} \mathrm{DCs}$ are present in the spleens of $\mathrm{HO}-1^{-1-}$ mice.

In conclusion, our studies show that the kinetics of HO-1 in BMDCs in response to LPS is dependent on culture conditions. $\mathrm{CD}^{+}$DCs express high levels of $\mathrm{HO}-1$ in vivo; this subpopulation is greatly reduced in HO-1-deficient mice, and the differentiation of $\mathrm{CD}^{+}$ DCs or homing of their precursors is dysregulated in $\mathrm{HO}-1$ knockout mice. It is possible that the defect in expression of $\mathrm{CD}^{+} \mathrm{DCs}$ could be related to the immunological abnormalities observed in the absence of HO-1 expression.

\section{References}

1. Tenhunen R, Marver HS, Schmid R: The enzymatic conversion of heme to bilirubin by microsomal heme oxygenase. Proc Natl Acad Sci USA 1968, 61:748-755

2. Tracz MJ, Alam J, Nath KA: Physiology and pathophysiology of heme: implications for kidney disease. J Am Soc Nephrol 2007, 18:414-420

3. Maines MD, Gibbs PE: 30 some years of heme oxygenase: from a "molecular wrecking ball" to a "mesmerizing" trigger of cellular events. Biochem Biophys Res Commun 2005, 338:568-577

4. Bach FH: Heme oxygenase-1 as a protective gene. Wien Klin Wochenschr 2002, 114(Suppl 4):S1-S3

5. Balla J, Vercellotti GM, Jeney V, Yachie A, Varga Z, Eaton JW, Balla G: Heme, heme oxygenase and ferritin in vascular endothelial cell injury. Mol Nutr Food Res 2005, 49:1030-1043

6. Nath KA, Vercellotti GM, Grande JP, Miyoshi H, Paya CV, Manivel JC, Haggard JJ, Croatt AJ, Payne WD, Alam J: Heme protein-induced chronic renal inflammation: suppressive effect of induced heme oxygenase-1. Kidney Int 2001, 59:106-117

7. Nath KA, Haggard JJ, Croatt AJ, Grande JP, Poss KD, Alam J: The indispensability of heme oxygenase- 1 in protecting against acute heme protein-induced toxicity in vivo. Am J Pathol 2000, 156: $1527-1535$

8. Agarwal A, Balla J, Alam J, Croatt AJ, Nath KA: Induction of heme oxygenase in toxic renal injury: a protective role in cisplatin nephrotoxicity in the rat. Kidney Int 1995, 48:1298-1307

9. Poss KD, Tonegawa S: Reduced stress defense in heme oxygenase 1-deficient cells. Proc Natl Acad Sci USA 1997, 94:10925-10930

10. Kotsch K, Martins PN, Klemz R, Janssen U, Gerstmayer B, Dernier A, Reutzel-Selke A, Kuckelkorn U, Tullius SG, Volk HD: Heme oxygenase-1 ameliorates ischemia/reperfusion injury by targeting dendritic cell maturation and migration. Antioxid Redox Signal 2007, 9:2049-2063

11. Abraham NG, Kappas A: Pharmacological and clinical aspects of heme oxygenase. Pharmacol Rev 2008, 60:79-127

12. Kapturczak MH, Wasserfall C, Brusko T, Campbell-Thompson M, Ellis TM, Atkinson MA, Agarwal A: Heme oxygenase-1 modulates early inflammatory responses: evidence from the heme oxygenase-1-deficient mouse. Am J Pathol 2004, 165:1045-1053

13. Poss KD, Tonegawa S: Heme oxygenase 1 is required for mammalian iron reutilization. Proc Natl Acad Sci USA 1997, 94:10919-10924

14. George JF, Braun A, Brusko TM, Joseph R, Bolisetty S, Wasserfall $\mathrm{CH}$, Atkinson MA, Agarwal A, Kapturczak MH: Suppression by $\mathrm{CD} 4{ }^{+} \mathrm{CD}_{25}{ }^{+}$regulatory T cells is dependent on expression of heme oxygenase-1 in antigen-presenting cells. Am J Pathol 2008, 173: $154-160$

15. Shortman K, Naik SH: Steady-stage and inflammatory dendritic cell development. Nat Rev Immunol 2007, 7:19-30

16. Rémy S, Blancou P, Tesson L, Tardif $\mathrm{V}$, Brion R, Royer PJ, Motterlini R, Foresti R, Painchaut M, Pogu S, Gregoire M, Bach JM, Anegon I, Chauveau C: Carbon monoxide inhibits TLR-induced dendritic cell immunogenicity. J Immunol 2009, 182:1877-1884

17. Chauveau C, Rémy S, Royer PJ, Hill M, Tanguy-Royer S, Hubert FX, Tesson L, Brion R, Beriou G, Gregoire M, Josien R, Cuturi MC, Anegon I: Heme oxygenase-1 expression inhibits dendritic cell maturation and proinflammatory function but conserves IL-10 expression. Blood 2005, 106:1694-1702

18. Mashreghi MF, Klemz R, Knosalla IS, Gerstmayer B, Janssen U, Buelow R, Jozkowicz A, Dulak J, Volk HD, Kotsch K: Inhibition of dendritic cell maturation and function is independent of heme oxygenase 1 but requires the activation of STAT3. J Immunol 2008, 180:7919-7930

19. Shiraishi F, Curtis LM, Truong L, Poss K, Visner GA, Madsen K, Nick HS, Agarwal A: Heme oxygenase-1 gene ablation or expression modulates cisplatin-induced renal tubular apoptosis. Am J Physiol Renal Physiol 2000, 278:F726-F736

20. Schaefer BC, Schaefer ML, Kappler JW, Marrack P, Kedl RM: Observation of antigen-dependent $\mathrm{CD}^{+}{ }^{+} \mathrm{T}$ cell/dendritic cell interactions in vivo. Cell Immunol 2001, 214:110-122

21. Lutz MB, Kukutsch N, Ogilvie AL, Rössner S, Koch F, Romani N Schuler G: An advanced culture method for generating large quantities of highly pure dendritic cells from mouse bone marrow. J Immunol Methods 1999, 223:77-92

22. Vremec D, Pooley J, Hochrein H, Wu L, Shortman K: CD4 and CD8 expression by dendritic cell subtypes in mouse thymus and spleen. J Immunol 2000, 164:2978-2986

23. Naik SH, Metcalf D, van Nieuwenhuijze A, Wicks I, Wu L, O'Keeffe M, Shortman K: Intrasplenic steady-state dendritic cell precursors that are distinct from monocytes. Nat Immunol 2006, 7:663-671

24. Wilson NS, El-Sukkari D, Belz GT, Smith CM, Steptoe RJ, Heath WR Shortman K, Villadangos JA: Most lymphoid organ dendritic cell types are phenotypically and functionally immature. Blood 2003, 102:2187-2194

25. Vremec D, Shortman K: The isolation and identification of murine dendritic cell populations from lymphoid tissues and their production in culture. Methods Mol Biol 2008, 415:163-178

26. Naik SH, Sathe P, Park HY, Metcalf D, Proietto AI, Dakic A, Carotta S, O'KeeffevM, Bahlo M, Papenfuss A, Kwak JY, Wu L, Shortman K: Development of plasmacytoid and conventional dendritic cell subtypes from single precursor cells derived in vitro and in vivo. Nat Immunol 2007, 8:1217-1226

27. Son YI, Egawa S, Tatsumi T, Redlinger RE Jr, Kalinski P, Kanto T: A novel bulk-culture method for generating mature dendritic cells from mouse bone marrow cells. J Immunol Methods 2002, 262:145-157

28. Morelli AE, Zahorchak AF, Larregina AT, Colvin BL, Logar AJ, 
Takayama T, Falo LD, Thomson AW: Cytokine production by mouse myeloid dendritic cells in relation to differentiation and terminal maturation induced by lipopolysaccharide or CD40 ligation. Blood 2001, 98:1512-1523

29. Paglia P, Chiodoni C, Monica Rodolfo M, Mario P: Colombo MP: murine dendritic cells loaded in vitro with soluble protein prime cytotoxic T lymphocytes against tumor antigen in vivo. J Exp Med 1996, 183:317-323

30. Porgador A, Snyder D, Gilboa E: Induction of antitumor immunity using bone marrow-generated dendritic cells. J Immunol 1996, 156:2918-2926

31. Exner M, Minar E, Wagner O, Schillinger M: The role of heme oxygenase-1 promoter polymorphisms in human disease. Free Rad Biol Med 2004, 37:1097-1104

32. Soares MP, Lin Y, Anrather J, Csizmadia E, Takigami K, Sato K, Grey ST, Colvin RB, Choi AM, Poss KD, Bach FH: Expression of heme oxygenase-1 can determine cardiac xenograft survival. Nat Med 1998, 4:1073-1077

33. Sato K, Balla J, Otterbein L, Smith RN, Brouard S, Lin Y, Csizmadia E, Sevigny J, Robson SC, Vercellotti G, Choi AM, Bach FH, Soares MP: Carbon monoxide generated by heme oxygenase- 1 suppresses the rejection of mouse-to-rat cardiac transplants. J Immunol 2001, 166:4185-4194

34. Tu CF, Kuo CH, Juang JH: Effects of heme oxygenase-1 transgenic islets on transplantation. Transplant Proc 2005, 37:3463-3467

35. Bach FH: Heme oxygenase-1 and transplantation tolerance. Hum Immunol 2006, 67:430-432

36. Yamashita K, Ollinger R, McDaid J, Sakahama H, Wang H, Tyagi S, Csizmadia E, Smith NR, Soares MP, Bach FH: Heme oxygenase- 1 is essential for and promotes tolerance to transplanted organs. FASEB J 2006, 20:776-778
37. Soares MP, Bach FH: Heme oxygenase-1 in organ transplantation. Front Biosci 2007, 12:4932-4495

38. Zhen-Wei X, Jian-Le S, Qi Q, Wen-Wei Z, Xue-Hong Z, Zi-Li Z: Heme oxygenase-1 improves the survival of discordant cardiac xenograft through its anti-inflammatory and antiapoptotic effects. Pediatr Transplant 2007, 11:850-859

39. Yachie A, Niida Y, Wada T, Igarashi N, Kaneda H, Toma T, Ohta K, Kasahara Y, Koizumi S: Oxidative stress causes enhanced endothelial cell injury in human heme oxygenase-1 deficiency. J Clin Invest 1999, 103:129-135

40. Ohta K, Yachie A, Fujimoto K, Kaneda H, Wada T, Toma T, Seno A, Kasahara $\mathrm{Y}$, Yokoyama $\mathrm{H}$, Seki $\mathrm{H}$, Koizumi S: Tubular injury as a cardinal pathologic feature in human heme oxygenase-1 deficiency. Am J Kidney Dis 2000, 35:863-870

41. Koizumi S: Human heme oxygenase-1 deficiency: a lesson on serendipity in the discovery of the novel disease. Pediatr Int 2007, 49:125-132

42. Listopad J, Asadullah K, Sievers C, Ritter T, Meisel C, Sabat R, Döcke WD: Heme oxygenase- 1 inhibits T cell-dependent skin inflammation and differentiation and function of antigen-presenting cells. Exp Dermatol 2007, 16:661-670

43. Henri S, Vremec D, Kamath A, Waithman J, Williams S, Benoist C, Burnham K, Saeland S, Handman E, Shortman K: The dendritic cell populations of mouse lymph nodes. J Immunol 2001, 167:741-748

44. Naik S, Vremec D, Wu L, O'Keeffe M, Shortman K: CD8- $\alpha^{+}$mouse spleen dendritic cells do not originate from the CD8- $\alpha$ dendritic cell subset. Blood 2003, 102:601-604

45. Dakic A, Shao QX, D'Amico A, O'Keeffe M, Chen WF, Shortman K, Wu $\mathrm{L}$ : Development of the dendritic cell system during mouse ontogeny. J Immunol 2004, 172:1018-1027 